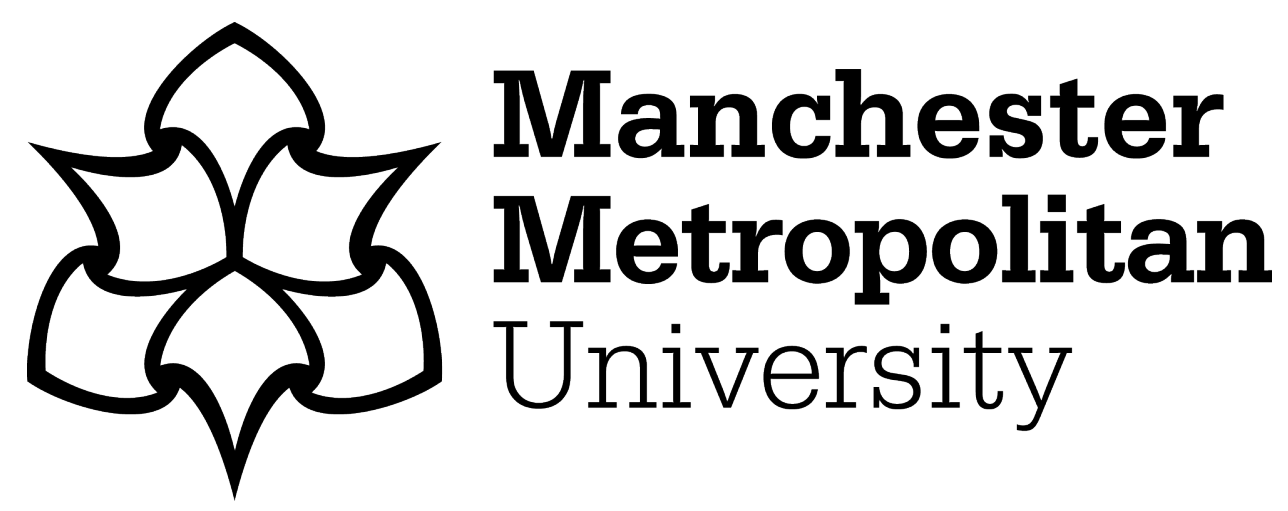

Craig, Elaine ORCID logoORCID: https://orcid.org/0000-0002-4252-3956 (2020) Child's Play or Sexual Abuse? Reviewing the Efficacy of the Justice Framework in Dealing with Child on Child Sexual Abuse in the United Kingdom. Journal of Child Sexual Abuse, 29 (6). pp. 734-748. ISSN 1053-8712

Downloaded from: https://e-space.mmu.ac.uk/625835/

Version: Accepted Version

Publisher: Taylor \& Francis (Routledge)

DOI: https://doi.org/10.1080/10538712.2020.1719448

Please cite the published version 


\title{
Child's Play or Sexual Abuse? Reviewing the Efficacy of the Justice Framework in Dealing with Child on Child Sexual Abuse in the United Kingdom
}

\author{
Elaine Craig \\ Manchester Metropolitan University, Manchester, UK
}

\begin{abstract}
This literature review appraises how the justice system of the United Kingdom deals with child on child sexual abuse allegations. It is crucial to consider the impact of minor sexual abuse within the community. Sensationalized reporting of sex crimes demonizes offenders and unintentionally hides some perpetrators by not representing children can cause harm. Cases where children demonstrate sexual agency are confusing and uncomfortable to appropriate blame. A freedom of information request to the Metropolitan Police uncovered 5,500 minor sex abuse allegations in England and Wales between 2011 and 2014, including, 4,000 physical assaults and 600 rape allegations. Officials caution these figures only represent a small proportion of known sexual abuse cases but the full extent of the problem is yet to be seen. Children are being exposed to explicit imagery far beyond their developmental age causing a blurring of the lines between normal sexual curiosity, harmful behavior, sexual deviance, and abuse. Evidence suggests societal failings and technological advances have created vulnerabilities from which new and dangerous sexual norms have evolved. Therefore, this paper reviews the justice, welfare, and restorative justice frameworks to explore the efficacy of the justice system in dealing with child on child sexual abuse in the UK.
\end{abstract}

\section{ARTICLE HISTORY}

Received 17 June 2019

Revised 2 January 2020

Accepted 8 January 2020

\section{KEYWORDS}

Child sexual abuse; child sex offender; sexual abuse; peer abuse; minor

Minor sex offenders (MSOs) are children under 18 years old who have persuaded, groomed, forced or coerced another person(s) of any age to engage in sexual act(s) or conduct, on or offline, in a non-consensual, threatening or exploitive manner (National Society for Prevention of Cruelty to Children [NSPCC], 2017; Ryan \& Otonichar, 2016). Research identifies this area as academically and statistically underrepresented and publicly misunderstood (Ryan \& Otonichar, 2016; Warner \& Bartels, 2015). The lack of statistics demonstrating MSO prevalence in the UK is partially due to legal criminality being 10 years of age (Brimicombe, 2016; Warner \& Bartels, 2015). Legal criminality is the age at which one can be held accountable for their actions if they violate public law (Baker et al., 2011). In an attempt to gather statistical data, the UK government-initiated crime surveys differentiating 
by the age of population; however, these tools are unsuccessful in collecting child on child sex abuse prevalence.

Victim of Crime Surveys do not depict child sex crime statistics and inadvertently obscure data by including a wide age range of 16 to 59year olds. Youth Justice crime surveys for 10 to 17 year olds, attempt to bridge the under 16-yearold gap but exclude children under 10 years old. Furthermore, it does not itemize sexual misconduct crime types due to the legal age of sexual consent being 16 years of age (Brimicombe, 2016; Youth Justice Statistics, 2015). Therefore, there is currently no successful means of collating data on child on child sexual abuse prevalence. Since all types of sexual misconduct are omitted from the surveys, young people who are experiencing unwanted sexual contact may not know what is happening to them is criminal. Likewise, child offenders who may be reenacting inappropriate sexual acts that they have experienced on their peers may not realize their actions are potentially criminal. This causes confusion in the discourse and thresholds of what is normal sexual experimentation and what is sexual abuse.

There were 38,575 recorded sexual offenses against children in 2014-2015 (Bently, O’Hagan, Raff, \& Bhatti, 2016; Office for National Statistics, 2016). Of these, 30,698 were victims under 16 years old, which is a $38 \%$ increase from 2013-2014 and an 85\% increase over the last 5 years. It is estimated that approximately one third of these offenses are perpetrated by minors (NSPCC, 2017). A freedom of information request to the Metropolitan Police uncovered 5,500 alleged minor sex offenses in England and Wales between 2011 and 2014 (Heede, 2016). This included 4,000 physical assaults and 600 rapes. Chief Constable Simon Bailey stated, "these figures are the tip of the iceberg" (Heede, 2016, p. 1; National Institute for Health Care and Excellence [NICE], 2016). Due to the lack of MSO research in the UK, the present article aims to examine the efficacy of the justice system in dealing with MSO cases in the UK by reviewing justice, welfare, and restorative justice frameworks.

MSOs are mistakenly assumed as being mini versions of adult sexual offenders, therefore, are misrepresented in policy and practice (Fanniff \& Becker, 2013; Ryan \& Otonichar, 2016; Warner \& Bartels, 2015). Research suggests this heterogeneous group have a different psychosocial make-up and behavior motivation patterns than adult sex offenders (Fanniff \& Kimonis, 2014; Ryan \& Otonichar, 2016). MSOs have a lower recidivism rate (i.e., $15 \%$ compared to $41.5 \%$ of non-sexual offenses), a greater response rate to treatment than adult sex offenders and commonly suffer with learning or cognitive dysfunctions and/or disabilities (Cale, Smallbone, Rayment-McHugh, \& Dowling, 2016; Christiansen \& Vincent, 2013; Fanniff \& Becker, 2013; Fanniff \& Kolko, 2012; Youth Justice Statistics, 2016). Hence, research should carefully consider whether minor sexual offender policies are built on adult offender theories to accurately evaluate the risks, safeguarding, rehabilitation, and interventions of child perpetrators (Cale et al., 2016; Warner \& Bartels, 2015). 
Legislation governing MSOs embodies three ideologies; welfare, justice, and restorative justice (Warner \& Bartels, 2015). Welfare upholds the child's humanitarian rights for example, the Convention of the Rights of the Child by the United Nations (1989) and the Children's Act (2004). Justice focuses on accountability and punishment, including the Sexual Offences Act (2003) and the Crime and Disorder Act (1998). Whereas restorative justice attempts to incorporate both elements as well as treatment, rehabilitation, and public interest guidance (Crown Prosecution Service, 2016a, 2016b, 2016c). Theoretically, this is an efficient model administering justice with care; however, examination has identified disparities between the theory and practice thereof (Ryan \& Otonichar, 2016; Warner \& Bartels, 2015).

A large proportion of MSO research is conducted in the USA. This may be due to mandatory reporting of sexual abuse allegations as well as criminal age being as low as seven years old in some states (Fitz-Gibbon, 2016). Some USA terms such as juvenile are not used in the UK. Nevertheless, research findings are applicable. Whilst this paper reviews justice, welfare, and restorative justice frameworks the later of the two are examined in more detail. This is due to a substantial lack of primary data in the justice framework for child on child sexual abuse. Future research should focus on policing MSO allegations to explore whether there is justice for victims of MSO without lifelong implications for perpetrators.

\section{Justice framework}

Justice frameworks begin with policing. Policing shapes discourses as to what sexual acts are viewed as serious crimes and what are considered mere child's play (Paterson \& Clamp, 2012). Rule 11, in Article 43 of The Convention of the Rights of Child favors diversion over judicial proceedings hence police issue formal youth cautions out of court (Crown Prosecution Service, 2016a, 2016b, 2016c). It aims to re-direct deviant behavior before escalating to criminalization. To facilitate out of court, low-level offending penalties without prosecution the UK police issue young people with verbal cautions. To reduce the subjectivity of the officer, these cautions must score between two and three on a 5-point Likert scale called the Association of Chief Police Officers Gravity Matrix (Crown Prosecution Service, 2013). A score of one to two indicates potentially harmful but not deviant behavior, scores of two to four are considered deviant behavior but not criminal, and scores four to five indicate potentially criminal behavior (Ministry of Justice, 2015) .

There is limited research on the caution scoring scale, but there are obvious limitations as they require the accused to first confess before being able to administer them (Cushing, 2014). There are no limits as to how many cautions one youth can receive. Moreover, a caution is not a proportional penalty considering the impact of sexual abuse on victims (Bateman, 2014; Fox \& 
Arnull, 2015; Paterson \& Clamp, 2012; Smith, Utting, \& Morgan, 2011; Zhang, Zhao, Zhao, \& Ren, 2016).

In the UK, Youth Justice Statistics (2016) claim young people given cautions for sexual offenses declined in 2015 by 14\%, from 401 to 346 . Nonetheless, charges for youth sexting and possession of indecent child images (discussed later in this paper) have reached an all-time high of 14,000. This suggests institutional denial in addition to the minimization of the severity of MSO is anchoring the child's play representation (Fox \& Arnull, 2015; Ministry of Justice, 2015, Section 10; Paterson \& Clamp, 2012; Warner \& Bartels, 2015).

The Gravity Matrix does include aggravating and mitigating circumstances. Nevertheless, most sexual activities score two (i.e., potentially harmful but not deviant) if the victim is aged 13 to 16 years old, and three only if victim is under 13 years of age. This includes engaging in sexual activity and causing another child to watch sexual acts (Crown Prosecution Service, 2013; Youth Justice Statistics, 2015). Scores increase to three (i.e., deviant but not criminal) in cases of inciting children into prostitution and administering substances with intent to commit sex acts. Scores of four, indicating criminality not deviance, are designated for cases like rape, sexual act(s) with another child family member or sexual activity with a mentally disordered victim (Crown Prosecution Service, 2013).

The Gravity Matrix scale is outdated and does not reflect current child sexual development research. NICE (2016) released a multi-agency guidelines paper to tackle appropriate sexual conduct. It advises four age categories of sexual development ( 0 to 5 years old, 5 to 9 years old, 9 to 13 years old and 13 to 17 years old) and uses Brook (2016) traffic light tool identifying sexual behaviors on a scale of green (i.e., normal/curious), amber (i.e., concerning) or red (i.e., unsafe or dangerous). Brook is an agency that offers sexual health advise and education for people under 25 years old. Their traffic light tool portrays amber and red behaviors as potentially harmful or deviant conduct outside of the developmental stage of the child, which services should refer for further investigation. In order to distinguish between curious, deviant, and criminal sexual behavior and to continue encouraging diversion, the Gravity Matrix should update their Likert scoring with Brook's guidelines and have a procedure flagging the number of amber/red cautions one youth receives.

Guidelines emphasize sexual allegations must be dealt with as soon as possible to maximize the impact on the offender. However, sexual allegations, from initial reporting to trail proceedings, have the highest waiting time of approximately 328 days compared to 89 for non-sexual offenses (Ministry of Justice, 2015, Section 10). The quantity of bureaucracy involved after being cautioned slows this process down. When deciding whether to prosecute the accused, police must investigate (1) the circumstances of the act, (2) the character of the accused, (3) the home life of the accused as well as (4) the victim(s) and families' wishes (5) the ages of the 
victim and the accused (6) any previous or current romantic relations between the victim and the accused in addition to other details (Crown Prosecution Service, 2016a, 2016b). This suggests broader forces affecting police resources cause police to prioritize cases of high tabloid attention. Therefore, MSO minimization may not be intentional but goal orientated for operational efficacy (Elliott-Davies, Donnelly, Boag-Munroe, \& Van Mechelen, 2016).

The two-billion-pound budget cut from the Ministry of Justice meant losing 15,000 justice system professionals (Pitts, 2015). Consequently, Greater Manchester police had to cut 2,700 jobs between 2011-2015 amid of Rotherham and Rochdale sexual exploitation cases involving 1,400 victims (Jay, 2014; Pitts, 2015). In order to police MSOs adequately, resources at a governmental level must be increased, severity Matrix scales need updating, and proportional penalties must be established (Elliott-Davies et al., 2016).

\section{Welfare framework}

The age of criminal responsibility is disputed domestically and internationally (Fitz-Gibbon, 2016). Article 40 in the Convention of the Rights of the Child by the United Nations (1989) states parties should establish an age of criminality, recommending 12 years of age. The Crime and Disorder Act (1998) deemed a child incapable of crime under 10 years old due to a presumption of doli incapax (i.e., Section 34). Doli incapax deems a child incapable of forming intent and is therefore, criminally inculpable. Having an age threshold is necessary to hold individuals accountable to a standardized moral behavior code amidst a mass population in order to create community safety and protection (Croft, 2016; Fitz-Gibbon, 2016). However, it is naive to think a child goes to bed at nine years old criminally irresponsible and wakens on their tenth birthday fully responsible. To protect the child's welfare the United Nations Standard Minimum Rules for the Administration of Juvenile Justice (1985) states the child's emotional, mental, and intellectual maturity should be considered. Hence, the accused's character, home life, and the circumstances of the act of the accused are investigated (Crown Prosecution Service, 2016a, 2016b). This forces the practice of the law to align with psychological development theories to inform mental capacity (Fitz-Gibbon, 2016; Goldson, 2013; McDarmid, 2013).

In order to determine the capacity to engage in a sex crime, a child would have to understand what they are doing, know it is wrong, know it is against the law, have agency over their actions, and demonstrate volition (Goldson, 2013; McDiarmid, 2013). Commonalities of incarcerated MSOs include academic dysfunctions, learning disabilities and mental illness (Cale et al., 2016). Research is saturated in the central debate of cognitive capacity in relation to age and neural development with a large proportion of professionals supporting the age to be increased to 12 years old (Carroll, 2016; Church, Goldson, Hindley, 
\& McDiarmid, 2013; Croft, 2016; Luciana, 2013). Arguments for the 10 years of age threshold claim the UK has better education systems therefore, children are maturing earlier and do not need the protection of the law (Fitz-Gibbon, 2016). However, these assumptions omit references to the experiences or views of children. The psycho-social dynamics of what minors think sexual consent and sexual boundaries are, is imperative to measure emotional, mental, and intellectual maturity to validate criminal capacity. Therefore, appraising whether the sexual educational programs in the UK have successfully enhanced children's knowledge of and ability to cope with wanted and unwanted sexual experiences will help advise the age of culpability threshold.

A Cochran Collaboration review representing 15,903 pupils assessed the value of school taught programs in the prevention of teen dating violence. They found no evidence that school programs improved children's attitudes, behaviors, or knowledge of how to deal with sexual abuse, sexual boundaries or behaviors (Fellmeth, Heffernan, Nurse, Habibula, \& Sethi, 2013). A survey of 1,000 parents of 4 to 16 -year olds demonstrated $78 \%$ of parents were uncomfortable talking to their children about sexual issues and wanted schools to teach sexual boundaries, safe and unsafe touch, sexting, pornography, and what to do if these situations arise (National Children's Bureau, 2014). However, $80 \%$ of teachers claimed they were unequipped and needed help to teach such topics. Reports have shown year seven primary school children during sexual education classes asking teachers, "if I have a girlfriend, do I need to strangle her when I have sex?" (Elgot, 2016, p. 1).

This disparity between classroom teaching and real life was supported by a National Union of Students (2015) survey where 2,500 students stated sex and relationship education is treated as a science lesson, only teaching about puberty, contraception, and anatomy. Two thirds of participants said sexual boundaries such as consent were never taught. Furthermore, $60 \%$ of participants admitted turning to pornography to fill educational gaps: many describing pornography as helpful (National Union of Students, 2015). The Thames Valley Police (2015) released a Consent is like a Cup of Tea television campaign to try and address these concerns. Whilst largely supported by parents, there is no academic research appraising this canvass. In light of parental diversion, unequipped teachers, unsuccessful education programs and children naming pornography as sexually educational, referring to consent as making tea minimizes the seriousness of minor sex offenses. This anchors the child's play construction of deviant and concerning sexual behavior and fails to teach the criminal consequences of minor sexual abuse (Fellmeth et al., 2013; National Children's Bureau Sex Education Forum, 2014; National Union of Students, 2015).

Viewing pornography is a common characteristic of MSOs (Cale et al., 2016; Christiansen \& Vincent, 2013; Fanniff \& Becker, 2013; Ryan \& Otonichar, 2016). Whilst this is not a cause and effect relationship there is significant research demonstrating the correlation of viewing pornography 
with unhealthy sexual boundaries and unrealistic expectations, such as, objectifying partners and normalizing violence (Bonomi et al., 2014; Children's Commissioner, 2016; Horvath, Massey, Pina, Scally, \& Adler, 2013). Technological advances and the Internet (e.g., smart phones, social media apps, dating apps, chat rooms, and Skype) has transformed the way the world interacts relationally including intimate partnerships (Puccio \& Havey, 2016). A survey of 1000 young people in England aged 14 to 17 years old showed $44 \%$ of females and $32 \%$ of males admitted sending a naked or explicit sexual picture text (i.e., sext) and $49 \%$ of females and $47 \%$ of males have received a sext (Barter, Wood, Aghtaie, Larkins, \& Stanley, 2015). Reasons young people gave for sending one included that their partner requested it (56\%), to feel sexy (51\%), and as a demonstration of commitment $(43 \%)$. These reasons underline the emotional, mental, and intellectual immaturity of children when it comes to relational and sexual behaviors.

Young people do not understand the boundaries of healthy and harmful sexual behaviors. Although some may know their actions are wrong, they do not comprehend criminality or consequences thereof (Barter et al., 2015; Children's Commissioner, 2016; Heede, 2016; NICE, 2016). This is evident by statistics showing the prevalence of sexting. The Crown Prosecution Service recorded 14,000 charges of sext images and 3,800 charges for possession of indecent child images in 2014 (Pitts, Youth Crime and Youth Justice, 2015). It is common for MSOs to be found with explicit, violent sexual imagery of adults, children, and bestiality which again, demonstrates minors poor understanding of healthy and harmful sexual behaviors and boundaries (Ryan \& Otonichar, 2016; Warner \& Bartels, 2015).

NICE (2016) acknowledged children are being exposed to explicit imagery far beyond their developmental age. This is causing a blurring of the lines between their knowledge of normal sexual curiosity, harmful sexual behavior, sexual deviance, and abuse. The parental and educational failings along with technological advances have created vulnerabilities from which new and dangerous sexual norms have evolved (NICE, 2016; Puccio \& Havey, 2016). The implications of societal failings, and professional assumptions omitting views of the world children live in, mean we risk criminalizing a poorly educated and emotionally immature generation when it comes to sexual issues (Croft, 2016). This is not to excuse the minority who knowingly cause sexual harm to others. However, this examination demonstrates the majority of the capacity of the minors is impeded due to emotional, mental, and intellectual sexual immaturity.

To address societal failings parents and teachers should be given access to the NICE guidance (NICE, 2016) and the Brook Sexual Behaviors Traffic Light Tool Box (Brook, 2016). Brook (the sexual health agency for people under 25 years old) should collaborate with the NSPCC and the Child Exploitation and Online Protection to create and deliver age-specific sexual 
behavior education programs in schools. These should be academically appraised annually to stay current to the world children live in. Additionally, Brook's Traffic Light Tool (2016) outlining an age appropriate helpful to harmful sexual behavior scale should be used to inform a new police campaign to replace Consent is like a Cup of Tea. This should be devised for the four age categories specifying (in age-appropriate terms) green, amber, and red sexual behaviors. In addition to this, integrating the new sexual education school programs into TV storylines of popular young people's TV soaps may aid bridging the gaps between school and real-life disparities, including setting specific phone helplines for victims (Hartley, Wight, \& Hunt, 2016).

\section{Restorative justice framework}

The Code for Crown Prosecutors (2017a) states that prosecutors must consider public interest factors (i.e., the impact of the crime morally and ethically on the community) when deciding whether to prosecute. The return or discovery of a sex-offender in the community has resulted in community distress, caused unwanted media attention, and fueled public panic to the extent that communities have formed vigilante pedophile hunting groups (Boone \& Van de Bunt, 2016; Huey, Nhan, \& Broll, 2013). In Michigan, United States, Jamar Pinkney Jr, a 15-year-old boy, confessed to his mother to sexually touching his younger sister (United States District Court for the Eastern District of Michigan Southern Division, 2016). His mother called his father at work for advice. After returning from work his father, Jamar Pinkney Sr. aged 37, stripped his son naked, walked him to a field and shot him in the face. He was sentenced with first-degree premeditated murder. Children are inadvertently viewed as society's moral barometer demonstrating the health of a community; therefore, it is crucial to consider the impact of child on child sexual offenses in the community (Bradford \& Myhill, 2015; Jewkes, 2010; Melrose, 2013).

The emotionally charged content of popular crime films are used to inform mainstream criminological knowledge (Kohm \& Greenhill, 2011). Pedophilic films make emotion central to understanding and use child sexual abuse as a moral context for otherwise abstract narratives. Crime victims are often portrayed as mirror opposites of the perpetrator unintentionally misinforming the public about who can cause harm (McEvoy \& McConnachie, 2016). Labels such as sex offender or pedophile can evoke associations with a population assumed to be impulsive, dangerous, violent, manipulative, and resistant to treatment. Such presumptions can impact legal policy support, such as the sex offender register, as well as impacting public beliefs/opinions about people who perpetrate sex offenses (Harris \& Socia, 2014). 
These sensationalized portrayals of crimes create social discourses of child molesters being adults, perverts, monsters, and predators (Harris \& Socia, 2016; Kohm \& Greenhill, 2011). This demonizes offenders and unintentionally hides child perpetrators by not representing that children can cause other children sexual harm. Cases where children demonstrate sexual agency are uncomfortable and confusing for juries to appropriate blame (Dodsworth, 2014; Niehaus, Jackson, \& Davies, 2010; Woodiwiss, 2014). It is easier to label a child born evil than address the inaccuracy of existing crime discourses. This is partially due to social ideals of a child epitomizing innocence, clashing with social construct of a sex offender whose criminality scores highest in a media-made crime hierarchy (Boone \& Van de Bunt, 2016; Bowman, 2016; Christie, 1986; Engbersen \& Van Der Leun, 2001; Flacks, 2012).

Part of the Crown Prosecution responsibility is to identify perpetrator(s), uncover prevalence and identify risk whilst skillfully minimizing moral panic (Boone \& Van de Bunt, 2016; Pilgrim, 2017). The current prevalence and therefore risk of minor sexual offenses is still significantly under researched in the UK. Professional discretion is a necessity to minimize moral panic whilst prevalence and risk are assessed and initial reactions of institutional denial and/or minimization are explored and addressed (Boone \& Van de Bunt, 2016; Leander, 2010; Pilgrim, 2017). However, sensitive, academically informed research into child on child sex abuse may aid the dispelling of mistaken assumptions, uncover prevalence by giving voice to victims, and reshape the inaccurate discourses of criminality (Bradford \& Myhill, 2015; Dodsworth, 2014; Kitzinger, 2004; McCartan, Kemshall, \& Tabachnick, 2015; Smolej, 2010; Surette, 2015). Hence, discretion whilst understanding minor sex crimes and not secrecy through institutional minimization is a key component in MSO restorative justice (Bowman, 2016).

\section{Conclusion and recommendations}

This paper examined the efficacy of the justice system in dealing with child on child sexual abuse in the UK. Children are being exposed to explicit imagery far beyond their developmental age causing a blurring of the lines between normal sexual curiosity, harmful sexual behavior, sexual deviance, and abuse. Hence, we risk criminalizing a poorly educated generation who lack maturity, skills, and knowledge in dealing with sexual issues.

Policing MSO impacts what is a serious crime and what is child's play; however, caution scales are outdated and are not a proportional penalty. Sexual allegation judicial procedures have the highest waiting time suggesting broader forces negatively affect police resources therefore minimization may not be intentional but goal orientated. To police minor sexual offenses adequately, the governmental must increase police resources, caution severity scales addressed, and proportional penalties established. Arguments for the 
10 -year-old criminally culpable threshold claim better education systems mean children mature earlier; however, these assumptions omit children's views. Parental diversion, unequipped teachers, unsuccessful sex education programs, and children citing pornography as sexually informative suggests the majority of children's capacity in sexual issues is impeded. Collaboration using the NICE (2016) guidance and the Brook (2016) to educate teachers, parents, build policing campaigns, school programs and integrate in soap storylines is a positive start to addressing these issues.

The Code for Crown Prosecutors must consider public interest whilst deciding to prosecute minor sex offenders. Professional discretion is a necessity to minimize panic. Sensitive, academic research is supported to aid the dispelling of mistaken assumptions, uncover prevalence and re-shape discourses of criminality. The integration of discretion, understanding child on child sexual offenses and avoidance of secrecy through denial or minimization is key to restorative justice.

\section{Disclosure of interest}

There are no known subjective and/or pharmacological discrepancies, no conflict of interest and no monetary gain for any parties. No funding was received to conduct this research.

\section{Ethical standards and informed consent}

As this is a review of the justice system in dealing with child on child sex allegations in the UK no ethical approval or informed consent were required.

\section{Notes on contributor}

Elaine Craig, BSC., MSc., MBPSS, is a Psychologist and Mental Health Research Assistant who contributes to research by designing and testing interventions spanning criminology, safeguarding, psychology \& vulnerable populations.

\section{ORCID}

Elaine Craig (1D) http://orcid.org/0000-0002-4252-3956

\section{References}

Baker, K., Kell, G., \& Wilkinson, B. (2011). Assessment in youth justice. The Policy Press. doi:10.1111/hojo.12031_3

Barter, C., Wood, M., Aghtaie, N., Larkins, C., \& Stanley, N. (2015). Safeguarding teenage intimate relationships connecting online and offline contexts and risks. Briefing paper 2: Incidence rates and impact of experiencing interpersonal violence and abuse in young 
people's relationships. Retrieved from https://www.safenet.bg/images/sampledata/files/ STIR-Briefing-Paper-2-English

Bateman, T. (2014). Where has all the youth crime Gone? Youth justice in an age of austerity. Children \& Society, 28(5), 416-424. doi:10.1111/chso.12087

Bently, H., O’Hagan, O., Raff, A., \& Bhatti, I. (2016). How safe are our children: The most comprehensive overview of child protection in the UK. NSPCC learning. Retrieved from https://www.nspcc.org.uk/services-and-resources/research-and-resources/2016/how-safeare-our-children-2016/

Bonomi, A. E., Nemeth, J. M., Altenburger, L. E., Anderson, M. L., Snyder, A., \& Dotto, I. (2014). Fiction or not? Fifty shades is associated with health risks in adolescent and young adult females. Journal of Women's Health., 23(9), 720-728. doi:10.1089/ jwh.2014.4782

Boone, M., \& Van de Bunt, H. (2016). Dynamics between denial and moral panic: The identification of convicted sex offenders. Probation Journal., 63(1), 23-40. doi:10.1177/ 0264550516637450

Bowman, C., . G. (2016). The legal system and child sex abuse-Ross chief s the witch-hunt narrative: Politics, Psychology, and the sexual abuse of children. Law \& Social Inquiry., 41 (1), 267-283. doi:10.1111/1si.12178

Bradford, B., \& Myhill, A. (2015). Triggers of change to public confidence in the police and criminal justice system: Findings from the crime survey for England and Wales. Criminology \& Criminal Justice., 15(1), 23-43. doi:10.1177/1748895814521825

Brimicombe, A. (2016). Analysing police-recorded data. Legal information management. Legal Information Management., 16(2), 71-74. doi:10.1017/S1472669616000207

Brook. (2016). Brook sexual behaviours traffic light tool. Sexual health and wellbeing from under 25s. Retrieved from https://www.brook.org.uk/our-work/category/sexual-behaviours -traffic-light-tool

Cale, J., Smallbone, S., Rayment-McHugh, S., \& Dowling, C. (2016). Offense trajectories, the unfolding of sexual and non-sexual criminal activity, and sex offense characteristics of adolescent sex offenders by sexual abuse. A Journal of Research and Treatment., 28(8), 791-892. doi:10.1177/1079063215580968

Carroll, J. E. (2016). Brain science and the theory of Juvenile mens rea. Law Review, 94(2), 569-573. Retrieved from: https://papers.ssrn.com/sol3/papers.cfm?abstract_id=2603647

Children's Act. (2004). (c.31). London. HMSO

Children's Commissioner. (2016). Online pornography: Young people's experiences of seeing online porn and the impact it has on them. Social welfare collections. Retrieved from https://www.bl.uk/collection-items/online-pornography-young-peoples-experiences-ofseeing-online-porn-and-the-impact-it-has-on-them

Christiansen, A. K., \& Vincent, J. P. (2013). Characterization and prediction of sexual and non-sexual recidivism among adjudicated Juvenile sex offenders. Behavioural Science and Law., 31, 506-529. doi:10.1002/bsl.2070

Christie, N. (1986). The ideal victim. In E. A. Fattah (Ed.), From crime policy to victim policy: Reorienting the justice system (pp. 17-30). Basingstoke, UK: Macmillan.

Church, R., Goldson, B., Hindley, N., \& McDiarmid, C. (2013). An age of complexity: Children and criminal responsibility in law. Youth Justice, 13(2), 145-160. doi:10.1177/ 1473225413492056

Code for Crown Prosecutors. (2017a). Annual report and accounts 2016-2017. Crown prosecution service. Retrieved from https://assets.publishing.service.gov.uk/government/uploads/ system/uploads/attachment_data/file/628968/CPS_annual_report_2016_17.pdf

Crime and Disorder Act. (1998). (c.37). London. HSMO 
Croft, T. (2016). Reforming the age of criminal responsibility. South African Journal of Psychology., 46(4), 436-448. doi:10.1177/0081246316640116

Crown Prosecution Service. (2013). ACPO youth offender case disposal gravity factor matrix. Youth justice resource hub. Retrieved from https://yjresourcehub.uk/yjb-effective-practice /youth-justice-kits/item/625-acpo-youth-gravity-matrix.html

Crown Prosecution Service. (2016a). Youth offenders. Legal guidance and youth crime. Retrieved from http://www.cps.gov.uk/legal/v_to_z/youth_offenders/

Crown Prosecution Service. (2016b). Minor offences. Legal guidance. Retrieved from http:// www.cps.gov.uk/legal/1_to_o/minor_offences/

Crown Prosecution Service. (2016c). Sexual offences. Prosecution guidance. Retrieved from https://www.cps.gov.uk/sexual-offences

Cushing, K. (2014). Diversion from prosecution for young people in England and Wales Reconsidering the mandatory admissions criteria. Youth Justice., 14(2), 140-153. doi: $10.1177 / 1473225414537568$

Dodsworth, J. (2014). Sexual exploitation, selling and swapping sex: Victimhood and agency. Child Abuse Review., 23, 185-199. doi:10.1002/car.2282

Elgot, J. (2016). Teach children about pornography before puberty says labour. The Guardian. Retrieved from https://www.theguardian.com/education/2016/nov/01/teach-childrenabout-pornography-before-puberty-says-labour

Elliott-Davies, M., Donnelly, J., Boag-Munroe, F., \& Van Mechelen, D. (2016). Getting a battering: The perceived impact of demand and capacity imbalance within the police service of England and Wales. The Police Journal: Theory, Practice and Principles, 89(2), 93-116. doi:10.1177/0032258X16642234

Engbersen, G., \& Van Der Leun, J. (2001). The social construction of illegality and criminality. European Journal on Criminal Policy and Research., 9(1), 51-70. doi:10.1023/ A:1011259422222

Fanniff, A. M., \& Becker, J. V. (2013). Adolescents adjudicated for sexual offences. In D. S. Bromberg \& W. T. O'Donohue (Eds.), Handbook of child and adolescent sexuality (pp. 519-539). Oxford: Elsevier Inc.

Fanniff, A. M., \& Kimonis, E. R. (2014). Juveniles who have committed sexual offenses: A special group? Behavioural Science and Law., 32, 240-257. doi:10.1002/bsl.2111

Fanniff, A. M., \& Kolko, D. J. (2012). Victim age based subtypes of juveniles adjudicated for sexual offenses: Comparisons across domains in an outpatient sample. Sexual Abuse: A Journal of Research and Treatment., 24(3), 224-264. doi:10.1177/1079063211416516

Fellmeth, G. L. T., Heffernan, C., Nurse, J., Habibula, S., \& Sethi, D. (2013). Educational and skills-based interventions for preventing relationship and dating violence in adolescents and young adults review. The Cochrane Database of Systematic Reviews. doi:10.1002/ 14651858.CD004534.pub3

Fitz-Gibbon, K. (2016). Protections for children before the law: An empirical analysis of the age of criminal responsibility, the abolition of Doli Incapax and the merits of a developmental immaturity defence in England and Wales. Criminology \& Criminal Justice., 16(4), 391-409. doi:10.1177/1748895816632579

Flacks, S. (2012). Youth justice reform: Redressing age discrimination against children? Youth Justice, 12(1), 19-35. doi:10.1177/1473225411435615

Fox, D., \& Arnull, E. (2015). Law and order conservatism and youth justice: Outcomes and effects in Canada, England and Wales. British Journal of Community Justice, 13(2), 79-86. Retrieved from https://www.mmuperu.co.uk/bjcj/articles/law-and-order-conservatism-and -youth-justice-outcomes-and-effects-in-canada 
Goldson, B. (2013). Unsafe, unjust and harmful to wider society: Grounds for raising the minimum age of criminal responsibility in England and Wales. Youth Justice., 13(2), 111-130. doi:10.1177/1473225413492054

Harris, A., \& Socia, J. (2014). What's in a name? Evaluating the effect of the "sex offender" label on public opinions and beliefs. Sexual Abuse, 28(7), 660-678. doi:10.1177/ 1079063214564391

Hartley, J., . E., Wight, D., \& Hunt, K. (2016). Presuming the influence of the media: Teenagers construction of gender identity through sexual/romantic relationships and alcohol consumption. Sociology of Health and Illness., 36(5), 772-786. doi:10.1111/1467-9566.12107

Heede, D. (2016). Response to harmful sexual behavior and prevention of further harm. Believe in children: Barnardos. Retrieved from http://www.barnardos.org.uk/hsb_ inquiry_-_summary_of_session_2_9_march_2016_.pdf

Horvath, M. A. H., Massey, K. L. A., Pina, A., Scally, M., \& Adler, J. R. (2013). Basically porn is everywhere. A rapid evidence assessment on the effects that access and exposure to pornography has on children and young people. The office of the children's commissioner. Retrieved from https://www.childrenscommissioner.gov.uk/wp-content/uploads/2017/07/ Basically_porn_is_everywhere.pdf

Huey, L., Nhan, J., \& Broll, R. (2013). Uppity civilians and cyber-vigilantes: The role of the general public in policing. Criminology \& Criminal Justice., 13(1), 81-97. doi:10.1177/ 1748895812448086

Jay, A. (2014). Independent inquiry into child sexual exploitation in Rotherham. Rotherham metropolitan council. Retrieved from https://www.rotherham.gov.uk/downloads/file/279/ independent-inquiry-into-child-sexual-exploitation-in-rotherham

Jewkes, Y. (2010). Much Ado About Nothing? Representations and realities of online soliciting of children. Journal of Sexual Aggression., 16(1), 5-18. doi:10.1080/13552600903389452

Kitzinger, J. (2004). Framing abuse: Media influence and public understandings of sexual violence against children. London, UK: Pluto.

Kohm, S., \& Greenhill, A. (2011). Pedophile crime films as popular criminology: A problem of justice? Theoretical Criminology, 15(2), 195-215. doi:10.1177/1362480610388974

Leander, L. (2010). Police interviews with child sexual abuse victims: Patterns of reporting, avoidance and denial. Child Abuse \& Neglect., 34(3), 192-205. doi:10.1016/j.chiabu.2009.09.011

Luciana, M. (2013). Adolescent brain development in normality and psychopathology. Development and Psychopathology., 25, 1325-1345. doi:10.1017/S0954579413000643

McCartan, K. F., Kemshall, H., \& Tabachnick, J. (2015). The construction of community understandings of sexual violence: Rethinking public, practitioner and policy discourses. Journal of Sexual Aggression, 21(1), 100-116. doi:10.1080/13552600.2014.945976

McDiarmid, C. (2013). An age of complexity: Children and criminal responsibility in law. Youth Justice, 13(2), 145-160. doi:10.1177/1473225413492056

McEvoy, K., \& McConnachie, K. (2016). Victimology in transitional justice: Victimhood, innocence and hierarchy. European Journal of Criminology., 9, 527-538. doi:10.1177/ 1477370812454204

Melrose, M. (2013). Twenty-first century party people: Young people and sexual exploitation in the new millennium. Child Abuse Review., 22, 155-168. doi:10.1002/car.2238

Ministry of Justice. (2015). Section ten: Offences committed by offenders under the age of 18 . Sexual offences guideline consultation. Retrieved from https://consult.justice.gov.uk/senten cing-council/child-sex-offences-young-offenders/supporting_documents/sexual\% 20 offences $\% 20$ consultation_Offences $\% 20$ committed $\% 20$ by $\% 20$ offenders $\% 20$ under $\% 20$ the \%20age\%20of\%2018.pdf 
National Children's Bureau Sex Education Forum (2014) Parents support sex and relationships education at primary school. The evidence. Retrieved from http://sexeducationforum. org.uk/policy-campaigns/parents-want-sre.aspx

National Institute for Health Care and Excellence (2016) Harmful sexual behaviour among children and young people. NICE guidelines. Retrieved from https://www.nice.org.uk/ guidance/ng55

National Society for Prevention of Cruelty to Children. (2017). Sexual abuse: What is sexual abuse? NSPCC. Retrieved from https://www.nspcc.org.uk/what-is-child-abuse/types-ofabuse/child-sexual-abuse/\#what-is

National Union of Students. (2015). Students turn to porn to fill the gaps in their sex education. Welfare and students rights. Retrieved from http://www.nus.org.uk/en/news/ students-turn-to-porn-to-fill-the-gaps-in-their-sex-education/

Niehaus, A. F., Jackson, J., \& Davies, S. (2010). Sexual self-schemas of female child sexual abuse survivors: Relationships with risky sexual behaviour and sexual assault in adolescence. Sexual Behaviour., 39, 1359-1374. doi:10.1007/s10508-010-9600-9

Office for National Statistics. (2016). Focus on violent crime and sexual offences year ending March 2015. Office for National Statistics. Retrieved from https://www.ons.gov.uk/people populationandcommunity/crimeandjustice/compendium/focusonviolentcrimeandsexualof fences/yearendingmarch 2015

Paterson, C., \& Clamp, K. (2012). Exploring recent developments in restorative policing in England and Wales. Criminology \& Criminal Justice., 12(5), 593-611. doi:10.1177/ 1748895812441933

Pilgrim, D. (2017). Child sexual abuse, moral panics and emancipatory practice. Critical and radical social work: Policy press. University of Liverpool. doi.10.1332/204986017X14835297996415

Pitts, J. (2015). Youth crime and youth justice 2015-2020. Youth and policy special edition: The next five years, prospects for young people. Retrieved from https://www.youthandpolicy.org/ wp-content/uploads/2017/06/pitts-yoht-crime-youth-justice-2015-2020.pdf

Puccio, D., \& Havey, A. (2016). Sex likes and social media. London, UK: Vermillion.

Ryan, E. P., \& Otonichar, J. M. (2016). Juvenile sex offenders. Sexual Disorders., 18, 65-67. doi:10.1007/s11920-016-0706-1

Sexual Offences Act. (2003). (c.42). London: HSMO.

Smith, D., . J., Utting, D., \& Morgan, R. (2011). Reforming the response to youth crime: From evidence to implementation. Journal of Children's Services., 6(2), 67-76. doi:10.1108/ 17466661111149367

Smolej, M. (2010). Constructing ideal victims? Violence narratives in finnish crime-appeal programming. Crime Media and Culture., 6(1), 69-85. doi:10.1177/1741659010363044

Surette, R. (2015). Thought bite: A case study of the social construction of a crime and justice concept. Crime Media Culture., 11(2), 105-135. doi:10.1177/1741659015588401

Thames Valley Police. (2015). Consent is like a cup of tea. Crime prevention. Consent is everything. Retrieved from https://www.thamesvalley.police.uk/police-forces/thames-valley -police/areas/c/2017/consent-is-everything/

United Nations. (1989). Convention on the rights of the child. New York, NY: Author.

United States District Court for the Eastern District of Michigan Southern Division. (2016, August 31). Case No.15-CV-12721. (E.D. Mich. Aug. 31, 2016). Retrieved from https:// casetext.com/case/pinkney-v-winn

Warner, K., \& Bartels, L. (2015). Juvenile sex offending: It's prevalence and the criminal justice response. University of New South Wales Law Journal, 38(1), 48-75. Retrieved from: https://papers.ssrn.com/sol3/papers.cfm?abstract_id=2586623 
Woodiwiss, J. (2014). Beyond a single story: The importance of separating 'Harm' from 'Wrongfulness' and 'Sexual Innocence' from 'Childhood' in contemporary narratives of childhood sexual abuse. Sexualities., 17, 139-158. doi:10.1177/1363460713511104

Youth Justice Statistics. (2015). Youth Justice Statistics 2015-2016 England and Wales. Ministry of Justice. Retrieved from https://assets.publishing.service.gov.uk/government/ uploads/system/uploads/attachment_data/file/585899/youth-justice-statistics-2015-2016executive-summary.pdf

Youth Justice Statistics. (2016). Youth justice statistics: 2015 to 2016. Ministry of justice England and Wales. Retrieved from https://www.gov.uk/government/uploads/system/ uploads/attachment_data/file/585897/youth-justice-statistics-2015-2016.pdf

Zhang, H., Zhao, R., Zhao, J. S., \& Ren, L. (2016). The impact of child sexual abuse and Psychological distress on delinquency. Crime, Law and Social Change, 66(5), 447-464. doi:10.1007/s10611-016-9637-3 